\title{
Towards Personalized Medicine: Non-Coding RNAs and Endometrial Cancer
}

\author{
Anna Franca Cavaliere ${ }^{1}$, Federica Perelli ${ }^{2, *}$, Simona Zaami ${ }^{3}\left(\mathbb{0}\right.$, Roberto Piergentili $\left.^{4}{ }^{(}\right)$, Alberto Mattei ${ }^{2}$, \\ Giuseppe Vizzielli ${ }^{5,6} \oplus$, Giovanni Scambia ${ }^{5}$, Gianluca Straface ${ }^{7}$, Stefano Restaino ${ }^{6} \odot$ and Fabrizio Signore ${ }^{8}$
}

1 Azienda USL Toscana Centro, Gynecology and Obstetric Department, Santo Stefano Hospital, 59100 Prato, Italy; annafranca.cavaliere@uslcentro.toscana.it

2 Azienda USL Toscana Centro, Gynecology and Obstetric Department, Santa Maria Annunziata Hospital, 50012 Florence, Italy; alberto.mattei@uslcentro.toscana.it

3 Department of Anatomical, Histological, Forensic and Orthopedic Sciences, Sapienza University of Rome, Viale Regina Elena 336, 00161 Roma, Italy; simona.zaami@uniroma1.it

4 Institute of Molecular Biology and Pathology, Italian National Research Council (CNR-IBPM), 00185 Rome, Italy; roberto.piergentili@cnr.it

5 Gynecologic Oncology Unit, Fondazione Policlinico Universitario A. Gemelli IRCCS, 00168 Rome, Italy; giuseppevizzielli@yahoo.it (G.V.); giovanni.scambia@policlinicogemelli.it (G.S.)

6 Obstetrics, Gynecology and Pediatrics Department, Udine University Hospital, DAME, 33100 Udine, Italy; Stefano.restaino@asufc.sanita.fvg.it

7 Division of Perinatal Medicine, Policlinico Abano Terme, 35031 Abano Terme, Italy; glstraface@gmail.com

8 Obstetrics and Gynecology Department, USL Roma2, Sant'Eugenio Hospital, 00144 Rome, Italy; fabrizio.signore@aslroma2.it

* Correspondence: federica.perelli@uslcentro.toscana.it; Tel.: +39-3338370040

Citation: Cavaliere, A.F.; Perelli, F.; Zaami, S.; Piergentili, R.; Mattei, A.; Vizzielli, G.; Scambia, G.; Straface, G.; Restaino, S.; Signore, F. Towards Personalized Medicine: Non-Coding RNAs and Endometrial Cancer. Healthcare 2021, 9, 965. https:// doi.org/10.3390/healthcare9080965

Academic Editor: Pedram Sendi

Received: 4 July 2021

Accepted: 26 July 2021

Published: 30 July 2021

Publisher's Note: MDPI stays neutral with regard to jurisdictional claims in published maps and institutional affiliations.

Copyright: (c) 2021 by the authors. Licensee MDPI, Basel, Switzerland. This article is an open access article distributed under the terms and conditions of the Creative Commons Attribution (CC BY) license (https:// creativecommons.org/licenses/by/ $4.0 /)$.

\begin{abstract}
Endometrial cancer (EC) is the most frequent female cancer associated with excellent prognosis if diagnosed at an early stage. The risk factors on which clinical staging is based are constantly updated and genetic and epigenetic characteristics have recently been emerging as prognostic markers. The evidence shows that non-coding RNAs (ncRNAs) play a fundamental role in various biological processes associated with the pathogenesis of EC and many of them also have a prognosis prediction function, of remarkable importance in defining the therapeutic and surveillance path of EC patients. Personalized medicine focuses on the continuous updating of risk factors that are identifiable early during the EC staging to tailor treatments to patients. This review aims to show a summary of the current classification systems and to encourage the integration of various risk factors, introducing the prognostic role of non-coding RNAs, to avoid aggressive therapies where not necessary and to treat and strictly monitor subjects at greater risk of relapse.
\end{abstract}

Keywords: endometrial cancer; molecular biology; non-coding RNA; competing endogenous RNA; biomarkers; prognostic factors; risk factors

\section{Introduction}

Endometrial cancer (EC) has been managed according to different classification systems based on several risk factors characteristic of each patient. Over the years, new risk factors related to the EC prognosis have been discovered and a better characterization of the disease has allowed a more precise treatment.

The first classification was mainly based on pathological aspects, from which endocrine, metabolic and clinical behavior derived. It was called the Bokhman's dualistic theory, according to which EC has been traditionally classified into the following two main groups: type I and type II [1].

The European Society for Medical Oncology (ESMO), the European Society of Gynecological Oncology (ESGO) and the European Society for Radiotherapy and Oncology 
(ESTRO) published a consensus in 2016 that defined six risk categories (low, intermediate, high-intermediate, high, advanced, metastatic) to better guide adjuvant therapy after staging surgery [2].

The Cancer Genome Atlas (TCGA) described for the first time in 2013 the following four distinct endometrial cancer subgroups: polymerase epsilon (POLE) mutated, hypermutated secondary to microsatellite instability (MSI), low copy number and high copy number, based on molecular features [3].

The Randomized phase III Trial of Molecular Profile based versus Standard Adjuvant Radiotherapy in Endometrial Cancer (PORTEC-4a) is an ongoing prospective, multicenter, randomized trial and is enrolling women with stage I EC classified as being within the high-intermediate prognostic group according to the ESMO/ESGO/ESTRO consensus. This subset of patients will be submitted to external beam radiation (EBRT), vaginal brachytherapy or no adjuvant treatment based on its molecular risk profile. The trial's aim is to compare the outcomes of patients who receive adjuvant vaginal brachytherapy, which is the current standard for high-intermediate risk EC, with EBRT or only follow up in cases of unfavorable or favorable molecular risk profile, respectively (NCT03469674) [4,5].

Recently, the ESGO, the ESTRO and the European Society of Pathology (ESP) updated an evidence-based guideline integrating clinical factors from the 2016 ESMO/ESGO/ESTRO with molecular factors from the TCGA molecular-based classification [6].

Non-coding RNAs (ncRNAs) are defined as transcripts of nucleotides with little or no protein-coding capacity. They have been associated with various malignant tumors as their deregulation can lead to changes in the function of oncogenes or tumor suppressors, showing their role in tumorigenesis. Their gene expression regulation can occur in different steps, at epigenetic, transcriptional, posttranscriptional and other stages [7]. Some deregulated ncRNAs have recently been emerging among the risk factors that can better define the EC behavior [8].

This review aims to summarize the clinical and biological risk factors on which the current classification systems are based and to include the ncRNAs among the prognostic factors to tailor treatments and oncological surveillance of each patient.

\section{Endometrial Cancer Overview}

EC is the most frequent female cancer in developed countries.

It affects about seventy-nine out of 100,000 women in Europe with a median age at diagnosis of sixty-two years $[9,10]$.

Several risk factors have been defined and grouped in metabolic alterations, such as obesity, diabetes, polycystic ovary syndrome (PCOS), genetic predisposition, such as Lynch Syndrome and Cowden Syndrome and other conditions such as tamoxifen use and infertility [11,12].

Due to the increase in the incidence of obesity worldwide, the incidence of EC is also significantly increasing [13].

The prognosis of EC patients seems to be closely linked to the stage of the disease at diagnosis.

An early stage EC patients' prognosis is generally favorable [9]. Currently, the treatment of patients with initial disease is based on EC risk factors: low risk patients are treated with surgery alone or followed by brachytherapy and/or EBRT, combined with platinum-based chemotherapy in stage I high risk and in stage II patients [2].

Advanced-stage EC patients show a higher risk of pelvic or distant recurrence, the greater for the non-endometrioid tumor histology [9]. For advanced-stage disease patients belonging to the high-risk group (i.e., stage III endometrioid tumor without residual disease after surgery, appropriately staged) the treatment involves EBRT, which represents the current standard, combined with chemotherapy in the context of clinical trials. Finally, for advanced or metastatic EC patients, surgery should only be considered to obtain a complete cytoreduction with no residual disease, and a systemic palliative treatment, 
such as carboplatin and paclitaxel-based chemotherapy or hormonal therapy, should be offered [2].

The 5-year overall survival (OS) is $95 \%$ for stage I women and $69 \%$ for stage II [9]. However, about $13 \%$ of high-risk patients and 3\% of women classified as low risk have a relapse [14]. The prognosis of patients affected by recurrent or advanced disease (stage III or IV) is poor, with 5-year OS rates related to metastatic disease ranging from 15 to 17\% [9].

Using that risk stratification based on the current classification systems, a percentage of patients is still overtreated or undertreated, up to $10 \%$ of early stage patients will experience distant metastasis and 7 high-intermediate risk patients need to undergo vaginal brachytherapy to prevent a recurrence [5].

For this reason, the researchers' efforts are currently focused on the genetic and epigenetic fields, in order to find unknown risk factors to better define EC patients' prognosis and management.

\section{Classification Systems of Endometrial Cancer and Related Risk Factors}

\subsection{Dualistic Model}

In 1981, Bokhman described the hypothesis that EC could be grouped into two categories that explained the different tumor behavior, especially linked to the prognosis of patients affected by the different types. He defined the so-called "two pathogenetic types" based on women's signs and the tumor's peculiarities and reported their influence on grading and the patient's survival [1].

Type I EC is generally associated with specific clinical and pathological features such as low grade (G1 or G2), rare LVSI, frequent prevalence of superficial myometrial invasion, long duration of symptoms that make an early diagnosis of the disease easier and favorable prognosis.

Type II EC is associated with high grade (G3), frequent LVSI, frequent prevalence of deep myometrial invasion, short duration or total absence of symptoms and doubtful prognosis.

\subsection{ESMO/ESGO/ESTRO Classification}

In 2016, Colombo et al., in the context of the ESMO/ESGO/ESTRO consensus on endometrial cancer and its diagnosis, treatment and follow-up, defined six risk groups for adjuvant therapy. The authors presented a classification system based on the following several prognostic factors: age, FIGO stage, depth of myometrial invasion, tumor differentiation grade, tumor histotype (endometrioid versus serous and clear cell) and LVSI [2].

- Age.

- $\quad$ FIGO stage. According to the FIGO (International Federation of Gynecology and Obstetrics) EC is classified in four stages based on the following three elements: the size of the tumor $(\mathrm{T})$, the loco-regional lymph nodes involvement $(\mathrm{N})$ and the spread to distant sites (M) [15] (Table 1).

Table 1. Endometrial cancer FIGO staging system.

\begin{tabular}{cc}
\hline FIGO Stage & Tumor Spread \\
Stage I & $\begin{array}{c}\text { The tumor is limited to the uterus } \\
\text { (it can affect the glands of the cervix and isthmus but not the } \\
\text { cervical stroma) }\end{array}$ \\
\hline IA & Myometrial invasion $<50 \%$ of its full thickness \\
\hline IB & Myometrial invasion $>50 \%$ of its full thickness \\
\hline Stage II & $\begin{array}{c}\text { The tumor involves the cervical stroma } \\
\text { (it does not invade tissues outside the uterus) }\end{array}$ \\
Stage III & $\begin{array}{c}\text { The tumor has spread outside the uterus } \\
\text { (it does not involve the rectum or bladder) }\end{array}$ \\
\hline IIIA & Uterine serosa and/or adnexa invasion \\
\hline
\end{tabular}


Table 1. Cont.

\begin{tabular}{cc}
\hline FIGO Stage & Tumor Spread \\
\hline IIIB & Vagina and/or parametrial invasion \\
\hline IIIC & Lymph nodes involvement \\
\hline IIIC1 & Pelvic lymph nodes involvement \\
\hline IIIC2 & Para-aortic lymph nodes involvement \\
\hline Stage IV & The tumor has spread to rectum, bladder or distant locations \\
\hline IVA & Rectum and/or bladder invasion \\
\hline IVB & Distant site metastasis \\
\hline
\end{tabular}

- $\quad$ Depth of myometrial invasion.

- Tumor differentiation grade.

- Tumor histotype.

- LVSI.

The above listed risk factors are grouped in six risk categories according to Colombo et al. [2] as reported in Table 2 .

Table 2. Endometrial cancer ESMO/ESGO/ESTRO classification system.

\begin{tabular}{|c|c|}
\hline Risk Category & Risk Factor Status \\
\hline Low & $\begin{array}{c}\text { FIGO Stage I } \\
\text { Endometrioid histotype } \\
\text { grade } 1-2 \\
<50 \% \text { myometrial invasion } \\
\text { LVSI negative }\end{array}$ \\
\hline Intermediate & $\begin{array}{c}\text { FIGO Stage I } \\
\text { Endometrioid histotype } \\
\text { grade } 1-2 \\
\geq 50 \% \text { myometrial invasion } \\
\text { LVSI negative }\end{array}$ \\
\hline High-intermediate & $\begin{array}{c}\text { FIGO Stage I } \\
\text { Endometrioid histotype } \\
\text { grade } 3 \\
<50 \% \text { myometrial invasion } \\
\text { regardless of LVSI status } \\
\text { OR } \\
\text { FIGO Stage I } \\
\text { Endometrioid histotype } \\
\text { grade } 1-2 \\
\text { LVSI unequivocally positive } \\
\text { regardless of depth of invasion }\end{array}$ \\
\hline High & $\begin{array}{c}\text { FIGO Stage I } \\
\begin{array}{c}\text { Endometrioid histotype } \\
\text { grade } 3\end{array} \\
\geq 50 \% \text { myometrial invasion } \\
\text { regardless of LVSI status } \\
\text { OR } \\
\text { FIGO Stage II } \\
\text { OR } \\
\text { FIGO Stage III } \\
\text { Endometrioid histotype } \\
\text { no residual disease } \\
\text { OR } \\
\text { Non-endometrioid histotype } \\
\text { (serous, clear-cell, undifferentiated carcinoma or carcinosarcoma) }\end{array}$ \\
\hline Advanced & $\begin{array}{l}\text { FIGO Stage III } \\
\text { residual disease } \\
\text { OR } \\
\text { Stage IVA }\end{array}$ \\
\hline Metastatic & FIGO Stage IVB \\
\hline
\end{tabular}




\subsection{TCGA Classification}

TCGA stands for The Cancer Genome Atlas and is a project aimed at creating a catalogue of the genetic mutations responsible for the various types of cancer. In 2013, the Cancer Genome Atlas Research Network contributed to the genomic characterization of EC. The authors performed an integrated genomic and proteomic analysis of 373 endometrial tumors and provided a diagnostic classification based on molecular biology [3].

They thus classified EC in four prognostic groups. Their molecular characterization data showed that approximately one quarter of endometrioid histotype and G3-graded tumors have a molecular phenotype similar to serous EC [16]. Since patients with endometrioid EC generally have a good clinical course, while those with serous histotype usually have a poor prognosis, the authors concluded that the molecular classification can lead to an improved management of these patients, assuming the tendency to treat tumors with specific and unfavorable genetic changes with chemotherapy instead of radiotherapy alone [3].

The authors reported four prognostic categories as follows:

(1) POLE ultramutated

Patients belonging to this subgroup show the best prognosis and the longer progressionfree survival.

The most frequent histotype associated with this genetic feature is endometrioid.

Some authors showed an association between POLE ultramutated and specific genes alterations, as follows: POLE, PTEN, PIK3R1, PIK3CA, FBXW7, KRAS, TP53 [17].

The POLE gene encodes the catalytic subunit A of DNA polymerase epsilon, which is involved in DNA replication and repair [14]. In EC patients, the most common mutations detected in POLE were P286R and S297F in exon nine and V411L, L424V and L424I in exon thirteen [18].

(2) Microsatellite instability hypermutated

Patients belonging to this subgroup show intermediate prognosis.

The most frequent histotype associated with this genetic feature is endometrioid.

Some authors showed an association between microsatellite instability hypermutated and specific genes alterations, as follows: PTEN, KRAS, ARID1A [17].

MSI represents the phenotypic evidence that DNA mismatch repair (MMR) is not functioning normally. MMR deficiency is linked to sporadic and inherited cancers of the colon, endometrium and brain. Biallelic inactivation of one of four

MMR genes (MLH1, MSH2, MSH6 or PMS2) results in an accumulation of mutations, the so-called MSI. The loss of MMR genes can occur through a combination of the following mechanisms: point mutations, small insertions or deletions, copy number changes, loss of heterozygosity, structural rearrangements and methylation of a gene promoter [19].

(3) Low copy-number

Patients belonging to this subgroup show intermediate prognosis.

The most frequent histotype associated with this genetic feature is endometrioid.

Some authors showed an association between a low copy-number and specific genes alterations, as follows: CTNNB1, PTEN [17].

Copy number changes are comprised in the genome structural variation: they consist in duplication or deletion events that affect a considerable number of DNA base pairs.

(4) High copy-number

Patients belonging to this subgroup show the worst prognosis.

The most frequent histotype associated with this genetic feature is serous.

Some authors showed an association between a high copy-number and specific genes alterations, as follows: TP53, FBXW7, PPP2R1A [17]. 


\subsection{PORTEC-4a Classification}

The PORTEC-4a is the first clinical trial applying molecular-integrated risk profiles in EC patients. It is a randomized trial of molecular-based versus standard recommendations to determine adjuvant treatment in women with early stage endometrial cancer.

Patients will be followed for vaginal recurrence after surgery if classified as "favorable molecular risk profile". They will be treated with vaginal brachytherapy if classified as "intermediate molecular risk profile". They will be treated with EBRT if classified as "unfavorable molecular risk profile". The primary endpoint is the vaginal recurrence, while the secondary endpoints are the recurrence-free and overall survival, the recurrence location, the adverse events incidence, the delayed symptoms and quality of life and EC-related healthcare costs [4].

The authors reported three prognostic categories as follows:

(1) Favorable:

- POLE mutation,

- or NSMP (No Specific Molecular Profile),

- without CTNNB1 mutations.

(2) Intermediate:

- Mismatch repair-deficient (MMRd),

- or NSMP,

- with CTNNB1 mutations.

(3) Unfavorable:

- substantial LVSI,

- TP53 abnormal immunohistochemical staining

- or L1CAM overexpression.

The CTNNB1 mutation causes the activation of the Wnt signaling pathway and has been shown to be associated with tumorigenesis in many types of human cancers. This gene encodes beta-catenin protein, which is involved in the Wnt signaling pathway and regulates cell growth, motility and differentiation [20]. Its mutation is associated with EC favorable prognosis.

P53 gene encodes for the tumor suppressor p53 protein (TP53). Its abnormal immunohistochemical staining is associated with poor EC prognosis: the loss of tumor suppressor p53 would result in a high degree of genomic instability and rapid tumor progression and invasion. The immunohistochemical staining abnormality reflects, as opposed to normal p53 wild-type staining, a mutational status of TP53. TP53 alteration causes the loss of genomic stability, DNA repair capacity, cellular senescence and apoptosis; it is one of the most frequent abnormalities in human cancer [21].

L1CAM is a 200 to $220 \mathrm{kDa}$ transmembrane protein of the immunoglobulin family, which may promote aggressive tumor behavior by driving cell proliferation, migration, invasion and metastasis [22]. It is associated with more aggressive EC hystologies, LVSI, advanced stage disease and more distant relapses [23].

\section{Epigenetic Risk Factors of EC}

The term epigenetics refers to heritable phenotype changes that do not involve alterations in the DNA sequence.

Epigenetic mechanisms consist of DNA methylation, histone modifications, nucleosome remodeling and modulation of the chromatin structure [24].

Human genomes have been shown to be divided into the following two groups: protein-coding messenger RNAs (mRNAs) and RNAs without coding potential, also known as noncoding RNAs (ncRNAs).

A non-protein-coding genome represents most of the whole mammalian genome.

Several authors demonstrated epigenetic signatures to be characteristic of many cancers. 
EC seems to be associated with gene function alterations mediated by ncRNA that may control cell mobility and invasion (important for metastasis formation), angiogenesis, resistance to chemotherapeutic agents and gene transcriptional regulation.

\section{1. ncRNA Role in EC Pathogenesis}

Non-coding RNAs (ncRNAs) are involved in many cellular processes and are associated with the tumorigenesis of several human cancers, showing abnormal expression patterns in many tumoral tissues. Some authors reported ncRNAs' deregulation as being responsible for the genesis and progression of various tumors and proposed their use as biomarkers for that disease [7].

As protein expression in EC seems to be altered, the protein coding regulation anomalies typically associated with RNA inhibitory activity have often been suggested [25-30].

NcRNAs do not have a coding protein capacity, but they can regulate gene expression and, acting in an oncogenic or tumor suppressor sense, they may promote various phases of tumorigenesis.

They are classified, according to their length, and defined as "long" ncRNAs (lncRNAs) in case of the presence of over 200 nucleotides, as "short" ncRNAs (sncRNAs) when they are made up of less than 200 nucleotides [7].

A subgroup of sncRNAs is represented by "micro" RNAs (miRNAs) that are usually composed of about 20 nucleotides.

Their role is to bind the target mRNA by silencing it, resulting in a reduction in that target mRNA expression, thus reducing the production of tumor suppressor proteins or indirectly increasing that of oncogene ones, contributing to the pathogenesis of several cancers.

\section{2. $n c R N A$ as Risk Factor for EC}

The ncRNAs can be classified in long and short ncRNAs and they can also be identified as competing endogenous RNAs (ceRNAs), as they can "compete" with the miRNAs binding them and restoring the coding capacity of the target mRNAs, free of the silencing effect of the link with the miRNAs [31].

The interaction between ceRNAs, miRNAs and mRNAs plays an important role in many cellular processes, including proliferation, apoptosis, angiogenesis, migration and invasion (formation of metastases) and cell cycle transition regulation [32].

This interaction occurs between homologous sequences, with an lncRNA that inhibits the binding of one miRNA to its mRNA target. This kind of interaction, and its deregulation, represents the basis of various types of cancer [33,34].

LncRNA and sncRNA are always expressed in the opposite sense, i.e., if the lncRNA is up-regulated (over-expressed), the corresponding miRNA is down-regulated, because more lncRNA molecules can bind the miRNA and the target mRNA expression is not reduced. Therefore, if the target mRNA encodes an oncogene, the up-regulation of the lncRNA makes it an oncogene (lncRNA and mRNA change together, increasing or decreasing at the same time), while the corresponding miRNA is functionally a tumor suppressor (inverse sign). The opposite mechanism is still valid.

Tables 3 and 4 show, respectively, the ncRNAs that play a role as an oncogene or a tumor suppressor in EC pathogenesis and for which a functional characterization is available (Tables 3 and 4).

The so-called "ceRNAs network" has been the subject of some studies that show the link between the ceRNAs alteration and some cancer characteristics and natural history, including EC [35]. 
Table 3. A summary of ncRNAs that play a role as oncogenes in EC pathogenesis and for which a functional characterization is available.

\begin{tabular}{|c|c|c|c|c|c|}
\hline ncRNA Name & Exp. & Function & miR Interactions & Mechanism & Refs. \\
\hline AL161431.1 & up & oncogene & $\operatorname{miR}-1252-5 p$ & a & [37] \\
\hline C2orf48 & up & oncogene & $\mathrm{miR}-183$ & $\mathrm{n} / \mathrm{a}$ & [38] \\
\hline CCAT1 & up & oncogene & miR-181a-5p & $\mathrm{n} / \mathrm{a}$ & {$[39,40]$} \\
\hline CСAT2 & up & oncogene & $\mathrm{miR}-216 \mathrm{~b}$ & $\mathrm{a} ; \mathrm{c}$ & [41] \\
\hline CDKN2B-AS & up & oncogene & miR-125a-5p & $\mathrm{d}$ & [42] \\
\hline CHL1-AS1 & up & oncogene & miR-6076 & $\mathrm{n} / \mathrm{a}$ & [43] \\
\hline circ_0002577 & up & oncogene & miR-197 & $a ; b ; e$ & {$[44,45]$} \\
\hline circ_0061140* & up & oncogene & miR-149-5p & a & [46] \\
\hline DANCR & up & oncogene & miR-214 & $\mathrm{b}$ & {$[47]$} \\
\hline DLEU1 & up & oncogene & $\operatorname{miR}-490$ & $\mathrm{~b} ; \mathrm{e}$ & {$[48,49]$} \\
\hline H19 & up & oncogene & miR-20b-5p; miR-124-3p; miR-612 & $\mathrm{a} ; \mathrm{b} ; \mathrm{c} ; \mathrm{e}$ & {$[50-55]$} \\
\hline HOTAIR * & up & oncogene & miR-646 & $\mathrm{b} ; \mathrm{f}$ & [56-62] \\
\hline HOXB-AS1 & up & oncogene & miR-149-3p & $\mathrm{a} ; \mathrm{c}$ & [63] \\
\hline LINC00483 & up & oncogene & miR-183; miR-192 & $\mathrm{b}$ & {$[38]$} \\
\hline LINC00958 & up & oncogene & miR-761 & c & {$[36]$} \\
\hline LINC01016 & up & oncogene & miR-302a-3p; miR-3130-3p & $\mathrm{n} / \mathrm{a}$ & [64] \\
\hline LINC01410 & up & oncogene & $\mathrm{miR}-23 \mathrm{c}$ & $\mathrm{a} ; \mathrm{b}$ & [65] \\
\hline LINC-ROR & up & oncogene & miR-145 & $\mathrm{n} / \mathrm{a}$ & {$[66]$} \\
\hline lnc-OC1 & up & oncogene & $\mathrm{miR}-34 \mathrm{a}$ & $\mathrm{b}$ & [67] \\
\hline lncRNA-ATB & up & oncogene & miR-126 & $\mathrm{a} ; \mathrm{b} ; \mathrm{e}$ & {$[68]$} \\
\hline LOXL1-AS1 & up & oncogene & $\operatorname{miR}-28-5 p$ & $\mathrm{a} ; \mathrm{b}$ & [69] \\
\hline NEAT1 & up & oncogene & miR-361; miR-144-3p; miR-146b-5p & a & {$[70-72]$} \\
\hline NR2F1-AS1 & up & oncogene & miR-363 & $\mathrm{a} ; \mathrm{b} ; \mathrm{c}$ & {$[73]$} \\
\hline PCGEM1 & up & oncogene & miR-129-5p & $\mathrm{a} ; \mathrm{c} ; \mathrm{b}$ & [74] \\
\hline PVT1* & up & oncogene & miR-195-5p & $\mathrm{a} ; \mathrm{b}$ & {$[75,76]$} \\
\hline RP11-357H14.17 & up & oncogene & $\begin{array}{l}\text { miR-24-1-5p; miR-27b; miR-143; miR-204; } \\
\text { miR-503; miR-4770 }\end{array}$ & $\mathrm{n} / \mathrm{a}$ & [77] \\
\hline RP11-89K21.1 & up & oncogene & $\begin{array}{l}\text { miR-27b; miR-4770; miR-143; miR-204; } \\
\text { miR-125a-5p; miR-125b-5p; } \\
\text { miR-139-5p; miR-670-3p }\end{array}$ & $\mathrm{n} / \mathrm{a}$ & [77] \\
\hline SNHG16 & up & oncogene & miR-490-3p & $\mathrm{a}$ & [78] \\
\hline SNHG8 & up & oncogene & miR-152 & $\mathrm{a}$ & [79] \\
\hline TUG1 & up & oncogene & miR-34a-5p; miR-299 & $\mathrm{n} / \mathrm{a}$ & {$[80]$} \\
\hline
\end{tabular}

ncRNAs are listed in alphabetical order (column 1) and for each we report its expression in EC compared to control (column 2) (either up- or down-regulated), its oncogenic function (column 3), its functional interactions with target miRNA (column 4) and its role in the development of EC (column 5) as reported in the available literature (column 6). In case of no data available, we report " $n / a$ ". In column 5, the following abbreviations were used: a: cell growth; b: apoptosis; c: cell invasion/migration; d: drug resistance; e: EMT transition; f: other. Data in the table are mostly retrieved from http:/ / www.bio-bigdata.com/lnc2cancer/, accessed on 10 March 2021 and updated according to the most recent (1/2018-onward) data available in PubMed (http:/ / pubmed.ncbi.nlm.nih.gov/, accessed on 10 March 2021). Note that ceRNAs marked with the symbol * can be up- and down-regulated, having both oncogenic and tumor suppressor functions; therefore, they are reported both in Tables 3 and 4. 
Table 4. A summary of ncRNAs that play a role as tumor suppressors in EC pathogenesis and for which a functional characterization is available.

\begin{tabular}{|c|c|c|c|c|c|}
\hline ncRNA Name & Exp. & Function & miR Interactions & Mechanism & Refs. \\
\hline circ_0061140* & down & tumor suppressor & miR-149-5p & $\mathrm{a}$ & [46] \\
\hline DCST1-AS1 & down & tumor suppressor & miR-92a-3p & c & [81] \\
\hline GAS5 & down & tumor suppressor & miR-103; miR-222-3p & $\mathrm{b}$ & {$[82,83]$} \\
\hline HOTAIR * & down & tumor suppressor & miR-646 & $b ; f$ & [56-62] \\
\hline LA16c-313D11.11 & down & tumor suppressor & miR-205-5p & $\mathrm{a} ; \mathrm{c}$ & [84] \\
\hline LINC00261 & down & tumor suppressor & $\begin{array}{l}\text { miR-27a; miR-96; miR-153; } \\
\text { miR-182; miR-183 }\end{array}$ & $\mathrm{a} ; \mathrm{c}$ & [85] \\
\hline LOC134466 & down & tumor suppressor & miR-196a-5p & $\mathrm{b}$ & [86] \\
\hline MALAT1 & down & tumor suppressor & miR-200c & $\mathrm{c} ; \mathrm{e}$ & [87] \\
\hline miR143HG & down & tumor suppressor & miR-125a & $b$ & [88] \\
\hline MIR22HG & down & tumor suppressor & miR-141-3p & $a ; b$ & [89] \\
\hline NIFK-AS1 & down & tumor suppressor & miR-146a & $\mathrm{a}$ & [90] \\
\hline PVT1 * & down & tumor suppressor & miR-195-5p & $\mathrm{a} ; \mathrm{b}$ & {$[78,79]$} \\
\hline RP11-395G23.3 & down & tumor suppressor & miR-205-5p & $\mathrm{a} ; \mathrm{c}$ & [91] \\
\hline SNHG5 & down & tumor suppressor & miR-25-3p & $\mathrm{a} ; \mathrm{c}$ & [92] \\
\hline TUSC7 & down & tumor suppressor & miR-23b; miR-616 & $\mathrm{a} ; \mathrm{e}$ & {$[93,94]$} \\
\hline
\end{tabular}

ncRNAs are listed in alphabetical order (column 1) and for each we report its expression in EC compared to control (column 2) (either upor down-regulated), its tumor suppressor function (column 3), its functional interactions with target miRNA (column 4) and its role in the development of EC (column 5) as reported in the available literature (column 6). In case of no data available, we report "n/a". In column 5, the following abbreviations were used: a: cell growth; b: apoptosis; c: cell invasion/migration; d: drug resistance; e: EMT transition; f: other. Data in the table are mostly retrieved from http:/ / www.bio-bigdata.com/lnc2cancer/, accessed on 10 March 2021 and updated according to the most recent (1/2018-onward) data available in PubMed (http:/ / pubmed.ncbi.nlm.nih.gov/, accessed on 10 March 2021). Note that ncRNAs marked with the symbol * can be up- and down-regulated, having both oncogenic and tumor suppressor functions; therefore, they are reported both in Tables 3 and 4 .

The most frequent mechanisms related to EC tumorigenesis deriving from the deregulation of the ceRNA network are uncontrolled cell growth, apoptosis alterations, deregulation of cell invasion and migration, drug resistance development, epithelial to mesenchymal transition (Tables 3 and 4).

Another great potential of ncRNAs identified by some authors, lies in the possibility of using these molecules as therapeutic targets for personalized medicine [36].

This would minimize the toxic effects of systemic therapies allowing a different targeted therapy for each subgroup of patients.

\section{3. ncRNA Selected for EC Patients Risk Stratification}

It is surprising to note that the association between ncRNA and EC has only recently been emerging in the literature, and that most of the papers regarding this association have been concentrated into the last three years.

A search of the PubMed database was carried out by two researchers independently and the following search strings were used: "endometrial cancer AND non coding RNA AND Kaplan-Meier" and "endometrial cancer AND competing endogenous RNA AND survival". Only papers related to the issue of the prognostic role of ceRNA in the context of EC and published from January 2018 to January 2021 were considered. The first search string retrieved 12 studies, including 20 ceRNAs correlated with the survival data of the patients under study. The second search string showed 11 studies regarding the prognostic role of 19 ceRNAs (a five-ceRNAs study derived from both search strings). Moreover, six ceRNAs were the subject of several selected studies; therefore, a total of 30 molecules were identified and considered for a prognostic stratification of EC patients.

Some ceRNAs, such as AC074212.1, ADARB2-AS1, C2orf48, C8orf49, C10orf91, FER1L4, FP671120.4, GLIS3-AS1, HOXB-AS1, LINC00483, LINC00491, LINC01143, LINC01352, 
LINC01410, LINC02381, MIR503HG, PCAT1, RP11-357H14.17 and RP11 89K21.1 seem to be associated with poor prognosis, while AL596188.1, KCNMB2-AS1, LA16c-313D11.11, LINC00237, LINC00475, LINC00958 and LNCTAM34A show a positive prognostic effect. Two ceRNAs, AC110491.1 and LINC00261, showed conflicting data, exhibiting an opposite prognosis in the different studies that analyzed them.

All the above-mentioned deregulations in ncRNAs expression were identified comparing EC tissue with normal endometrial tissue, similarly to what was performed for the collection of TCGA data.

Figure 1 shows the risk factors that should be considered for EC patients' stratifications to guarantee them an accurate and broad prognostic characterization, which takes into account both the established and emerging risk factors. They have been grouped into the following four classes: clinical, pathological, genetic and epigenetic prognostic factors. The clinical consolidated risk factor is represented by age at diagnosis; it assumes a negative prognostic value in case of older age. Among the pathological factors a higher FIGO stage and higher grading are related to the worst outcome, as for nonendometrioid hystotype and the presence of LVSI. The genetic alterations to consider for EC patients' stratification, derived from emerging evidence, are related to the following genes: POLE, MSI-related genes (MLH1, MSH2, MSH6 or PMS2), copy number changes, CTNNB1, TP53 and L1CAM. Finally, the epigenetic risk factors to consider in a wide stratification model should include those ceRNAs related to EC patients' survival outcome, as follows: AC074212.1, AC110491.1, ADARB2-AS1, AL596188.1, C2orf48, C8orf49, C10orf91, FER1L4, FP671120.4, GLIS3-AS1, HOXB-AS1, KCNMB2-AS1, LA16c-313D11.11, LINC00261, LINC00237, LINC00475, LINC00483, LINC00491, LINC00958, LINC01143, LINC01352, LINC01410, LINC02381, LNCTAM34A, MIR503HG, PCAT1, RP11-357H14.17 and RP11-89K21.1.
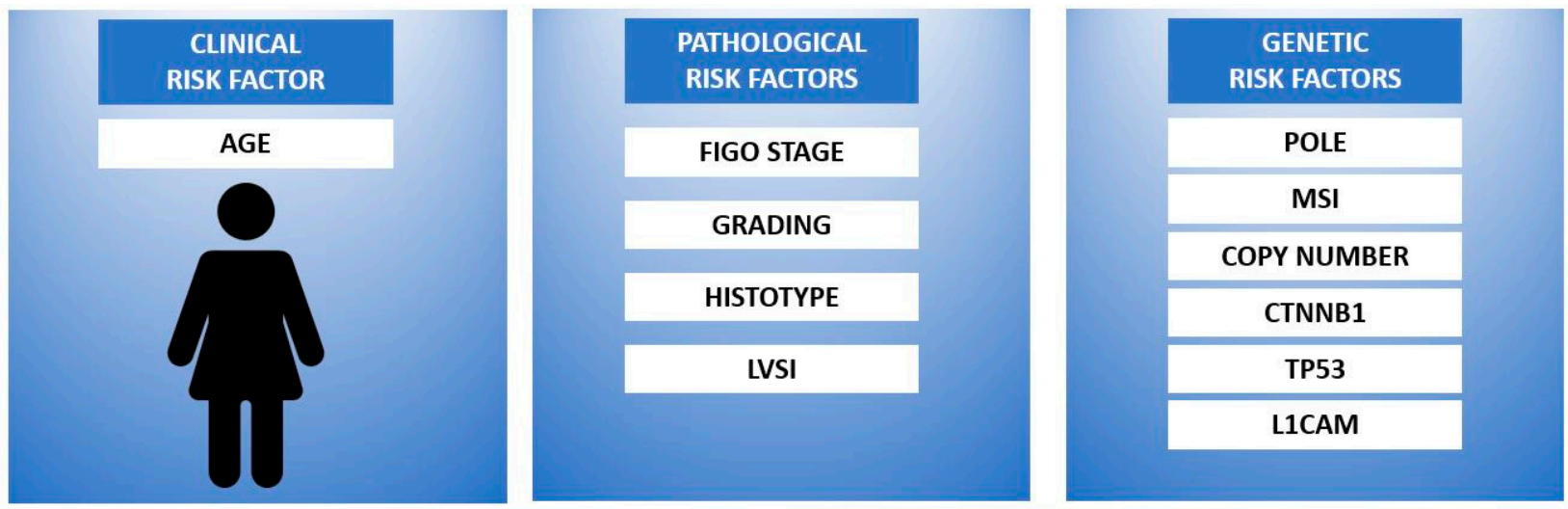

\begin{tabular}{|c|c|c|c|c|}
\hline EPIGENETIC & C2orf48 & HOXB-AS1 & LINC00483 & LINC02381 \\
\hline RISK FACTORS & C8orf49 & KCNMB2-AS1 & LINC00491 & LNCTAM34A \\
\hline AC074212.1 & C10orf91 & LA16C-313D11.11 & LINC00958 & MIR503HG \\
\hline AC110491.1 & FER1L4 & LINC00237 & LINC01143 & PCAT1 \\
\hline ADARB2-AS1 & FP671120.4 & LINC00261 & LINC01352 & RP11-357H14.17 \\
\hline AL596188.1 & GLIS3-AS1 & LINC00475 & LINC01410 & RP11-89K21.1 \\
\hline
\end{tabular}

Figure 1. EC patients risk stratification according to clinical, pathological, genetic and epigenetic prognostic factors.

In the epigenetic risk factors box, the ncRNAs are listed in alphabetical order. The data in the figure are retrieved from references [2-4,26,30,35,36,38,63,65,77,82,84,95-97]. 


\section{Discussion}

EC risk factors predicting a poor prognosis and ensuring an adequate treatment are currently being studied. Nowadays, research is increasingly oriented towards discovering genetic risk factors that can identify high-risk EC quickly and with non-invasive techniques. In this context, TCGA work has represented an epochal turning point for cancer patients' personalized management, allowing it to be selected according to genetic and epigenetic characteristics [3].

Epigenetic modifications are gaining increasing importance for the characterization of many diseases including cancer and a group of molecules is emerging as identifiable risk factors that help to establish clinical prognosis: the ncRNAs.

There is a correlation between some ncRNAs alterations and the predictive course of EC, representing the possibility of including these molecules in stratifying patients at greater risk of relapse and a poor outcome [8].

The current literature shows an upregulation or a downregulation of some types of ncRNAs in patients with EC compared to controls.

In particular, some studies have shown a correlation between EC patients' survival and the presence of specifically deregulated ncRNAs (Table 5).

Table 5. A summary of ncRNAs that play a role in EC prognosis.

\begin{tabular}{|c|c|c|c|c|c|c|}
\hline ncRNA Name & Exp. & Function & Deregulation-Related Prognosis & Author & Year & Refs. \\
\hline AC074212.1 & up & oncogene & poor & Wang, Y. & 2020 & [95] \\
\hline AC110491.1* & $\begin{array}{c}\mathrm{n} / \mathrm{a} \\
\text { down }\end{array}$ & $\begin{array}{c}\mathrm{n} / \mathrm{a} \\
\text { tumor } \\
\text { suppressor }\end{array}$ & $\begin{array}{l}\text { poor } \\
\text { good }\end{array}$ & $\begin{array}{l}\text { Ouyang, D. } \\
\text { Liu, J. }\end{array}$ & $\begin{array}{l}2019 \\
2019\end{array}$ & {$[26,38]$} \\
\hline ADARB2-AS1 ^ & $\begin{array}{l}\mathrm{n} / \mathrm{a} \\
\mathrm{n} / \mathrm{a}\end{array}$ & $\begin{array}{l}\mathrm{n} / \mathrm{a} \\
\mathrm{n} / \mathrm{a}\end{array}$ & $\begin{array}{l}\text { poor } \\
\text { poor }\end{array}$ & $\begin{array}{c}\text { Ouyang, D. } \\
\text { Xia, L. }\end{array}$ & $\begin{array}{l}2019 \\
2019\end{array}$ & {$[26,30]$} \\
\hline AL596188.1 & $\mathrm{n} / \mathrm{a}$ & $\mathrm{n} / \mathrm{a}$ & good & Ouyang, D. & 2019 & [26] \\
\hline C2orf48^ & $\begin{array}{l}\text { n/a } \\
\text { up }\end{array}$ & $\begin{array}{c}\mathrm{n} / \mathrm{a} \\
\text { oncogene }\end{array}$ & $\begin{array}{l}\text { poor } \\
\text { poor }\end{array}$ & $\begin{array}{l}\text { Ouyang, D. } \\
\text { Liu, J. }\end{array}$ & $\begin{array}{l}2019 \\
2019\end{array}$ & {$[26,38]$} \\
\hline C8orf49 & $\mathrm{n} / \mathrm{a}$ & $\mathrm{n} / \mathrm{a}$ & poor & Xia, L. & 2019 & [30] \\
\hline C10orf91 & $\mathrm{n} / \mathrm{a}$ & $\mathrm{n} / \mathrm{a}$ & poor & Ouyang, D. & 2019 & {$[26]$} \\
\hline FER1L4 & down & $\begin{array}{c}\text { tumor } \\
\text { suppressor }\end{array}$ & poor & Kong, Y. & 2018 & [82] \\
\hline FP671120.4 & up & oncogene & poor & Wang, Y. & 2020 & [95] \\
\hline GLIS3-AS1 & $\mathrm{n} / \mathrm{a}$ & $\mathrm{n} / \mathrm{a}$ & poor & Ouyang, D. & 2019 & [26] \\
\hline HOXB-AS1 & up & oncogene & poor & Liu, D. & 2020 & [63] \\
\hline KCNMB2-AS1 & up & oncogene & good & Tang, H. & 2019 & [96] \\
\hline LA16c-313D11.11 & down & $\begin{array}{c}\text { tumor } \\
\text { suppressor }\end{array}$ & good & Xin, W. & 2020 & [84] \\
\hline LINC00237 & $\mathrm{n} / \mathrm{a}$ & $\mathrm{n} / \mathrm{a}$ & good & Ouyang, D. & 2019 & [26] \\
\hline LINC00261* & $\operatorname{up}_{\text {down }}$ & $\begin{array}{l}\text { oncogene } \\
\text { tumor } \\
\text { suppressor }\end{array}$ & $\begin{array}{l}\text { good } \\
\text { poor }\end{array}$ & $\begin{array}{c}\text { Ouyang, D. } \\
\text { Zhao, D. }\end{array}$ & $\begin{array}{l}2019 \\
2019\end{array}$ & {$[26,35]$} \\
\hline LINC00475 & down & $\begin{array}{c}\text { tumor } \\
\text { suppressor }\end{array}$ & good & Tang, H. & 2019 & [96] \\
\hline LINC00483^ & $\operatorname{up}_{\mathrm{n} / \mathrm{a}}$ & $\begin{array}{c}\text { oncogene } \\
\mathrm{n} / \mathrm{a}\end{array}$ & $\begin{array}{l}\text { poor } \\
\text { poor }\end{array}$ & $\begin{array}{l}\text { Liu, J. } \\
\text { Xia, L. }\end{array}$ & $\begin{array}{l}2019 \\
2019\end{array}$ & {$[30,38]$} \\
\hline LINC00491^ & $\begin{array}{l}\mathrm{n} / \mathrm{a} \\
\mathrm{n} / \mathrm{a}\end{array}$ & $\begin{array}{l}\mathrm{n} / \mathrm{a} \\
\mathrm{n} / \mathrm{a}\end{array}$ & $\begin{array}{l}\text { poor } \\
\text { poor }\end{array}$ & $\begin{array}{c}\text { Xia, L. } \\
\text { Ouyang, D. }\end{array}$ & $\begin{array}{l}2019 \\
2019\end{array}$ & {$[26,30]$} \\
\hline LINC00958 & up & oncogene & good & Wang, Y. & 2019 & {$[36]$} \\
\hline LINC01143 & up & oncogene & poor & Tang, H. & 2019 & [96] \\
\hline LINC01352 & down & $\begin{array}{c}\text { tumor } \\
\text { suppressor }\end{array}$ & poor & Tang, H. & 2019 & [96] \\
\hline LINC01410 & up & oncogene & poor & $\mathrm{Lu}, \mathrm{M}$. & 2020 & [65] \\
\hline
\end{tabular}


Table 5. Cont.

\begin{tabular}{|c|c|c|c|c|c|c|}
\hline ncRNA Name & Exp. & Function & Deregulation-Related Prognosis & Author & Year & Refs. \\
\hline LINC02381 & up & oncogene & poor & Wang, Y. & 2020 & [95] \\
\hline LNCTAM34A & down & $\begin{array}{c}\text { tumor } \\
\text { suppressor }\end{array}$ & good & Wang, Y. & 2020 & [95] \\
\hline MIR503HG & down & $\begin{array}{c}\text { tumor } \\
\text { suppressor }\end{array}$ & poor & Tang, H. & 2019 & {$[96]$} \\
\hline PCAT1 & up & oncogene & poor & Zhao, X. & 2019 & [97] \\
\hline RP11-357H14.17 & up & oncogene & poor & Gao, L. & 2020 & [77] \\
\hline RP11-89K21.1 & up & oncogene & poor & Gao, L. & 2020 & [77] \\
\hline
\end{tabular}

ncRNAs are listed in alphabetical order (column 1) and for each we report its expression in EC compared to control (column 2) (either upor down-regulated), its tumor suppressor or oncogene function (column 3), its prognostic value (column 4 ) and the name of first author (column 5) and year of publication (column 6), as reported in the available literature (column 7). In case of no data available, we report "n/a". Data in the table are mostly retrieved from PubMed (http:/ / pubmed.ncbi.nlm.nih.gov/, accessed on 10 March 2021). Note that ncRNAs marked with the symbol * are associated to good and poor prognosis in different papers. NcRNAs marked with the symbol ^ have been the subject of multiple studies showing the same prognostic value.

In this review, we have selected the papers that demonstrated an association between EC patients' survival and the deregulation of specific ncRNAs.

The enormous value of the molecular finding lies in selecting patients who show a typical mapping of ncRNAs, making it possible to define the prognostic category and the most appropriate therapeutic and surveillance plan.

Furthermore, these molecules may represent diagnostic markers and therapeutic targets.

Therefore, it is evident that the old, dualistic classification of EC as type I and II [1] is no longer appropriate, and even that based on coding gene mutations is amply insufficient for the goal of personalized medicine.

The integrated classification strength is that ncRNAs can become both diagnostic, prognostic and therapeutic markers and for the first time the building of an "epigenetic profile" could assume a role in the treatment choice.

The new therapeutic strategy would consider the entire metabolic pathway of the identified altered molecules.

The weak point consists of the fact that, due to the multiple interactions between ceRNA-miRNA-mRNA, more targets are hit simultaneously, directly or indirectly. Therefore, it becomes difficult to look for a single modified protein to identify and treat EC effectively because some metabolic pathways are altered in several steps. A complete analysis of several molecules simultaneously would be appropriate to obtain a tailored medicine. Each patient is characterized by a specific set of molecular alterations, whose target is well defined, and that establishes the best therapeutic strategy. Making a selection of the available molecules with a prognostic value will be appropriate and will have to be the subject of future prospective studies. A possible limitation to the use of ncRNA as prognostic markers in clinical practice is represented by their tissue detection using quantitative real-time PCR, which requires the use of expensive fluorescently labeled probes.

Studying ncRNA expression based on current classifications to identify the correspondence between anatomical, genetic and epigenetic characteristics is a challenging goal.

Wang et al. demonstrated the superiority of the prognostic accuracy of multiRNA combined with clinical-stage over clinical stage alone, according to FIGO and over some genetic prognostic predictive models available in the literature [95].

Some recent reviews had already highlighted the role of ncRNAs in developing female cancers $[8,98,99]$, but they mainly focused on their mechanism in tumorigenesis. The present review is the first to identify and select a pool of ncRNAs that have a prognostic role and can influence the therapeutic choice based on the epigenetic profile of EC patients.

Finding a classification system that includes the integration of all the known risk factors would be a step towards truly tailored medicine. NcRNAs can be expressed in cancerous tissue but are also detectable in the blood circulation; therefore, they can be considered biomarkers. This would allow for not only their role in the EC prognostic 
classification but also in a future early diagnostic panel for several neoplasms. Moreover, the deregulation of the ncRNA correlating to the survival of EC patients selected by some studies (see Figure 1, epigenetic risk factors) seem to be epigenetic prognostic factors independent of the other currently established clinical risk factors.

The ongoing studies on genetic panels and integration between clinical and genetic factors will produce valuable data to identify more accurate oncological pathways for EC patients [4]. However, it is mandatory to also consider the epigenetic aspects of a tumor, detectable in the first phase by extraction from the tumor tissue, in a second phase from the circulating blood of EC patients. Figure 1 summarizes the old and new risk factors to be used for an optimal prognostic classification. For a complete risk stratification, it would be appropriate to create prospective data collections considering all the characteristics shown in Figure 1. In the hypothesis supported by some studies that clinical, genetic and epigenetic risk factors play an independent role, it would be necessary to study the prognostic accuracy of each prognostic factor taken individually and integrated with the others through multivariate analyses and logistic regressions.

It would be appropriate to collect all the reported risk factor information in a future observational and interventional study to obtain a global clinical and molecular characterization of EC, which would allow for the comparison of the various studies not only in terms of clinical outcomes but also regarding the molecular biology underlying tumor transformation and its diagnostic and therapeutic potential.

\section{Conclusions}

Therapeutic pathways tailored to the genetic and epigenetic characteristics of EC patients are the basis of precision medicine in oncology. Indeed, it could reduce the side effects of unnecessary therapies for patients without negative prognostic factors, while adequately treating high-risk EC patients.

Author Contributions: Conceptualization, G.S. (Giovanni Scambia), A.F.C., F.P. and R.P.; methodology, G.V., S.R., F.P.; software, G.V.; validation, F.P., S.R., G.V., R.P.; formal analysis, G.V., F.P.; investigation, A.F.C., S.Z., F.S., A.M.; resources, S.Z., F.S.; data curation, F.P., R.P.; writing-original draft preparation, A.F.C., F.P.; writing-review and editing, G.S. (Gianluca Straface), G.V., S.R.; visualization, S.Z., F.S., G.S. (Gianluca Straface), A.M.; supervision, G.S. (Giovanni Scambia), A.M.; project administration, A.M., G.S. (Giovanni Scambia); funding acquisition, A.M., G.S. (Giovanni Scambia). All authors have read and agreed to the published version of the manuscript.

Funding: This research received no external funding.

Institutional Review Board Statement: Not applicable.

Informed Consent Statement: Not applicable.

Conflicts of Interest: The authors declare no conflict of interest.

\section{References}

1. Bokhman, J.V. Two Pathogenetic Types of Endometrial Carcinoma. Gynecol. Oncol. 1983, 15, 10-17. [CrossRef]

2. Colombo, N.; Creutzberg, C.; Amant, F.; Bosse, T.; González-Martín, A.; Ledermann, J.; Marth, C.; Nout, R.; Querleu, D.; Mirza, M.; et al. ESMO-ESGO-ESTRO Consensus Conference on Endometrial Cancer: Diagnosis, Treatment and Follow-up. Ann. Oncol. 2016, 27, 16-41. [CrossRef] [PubMed]

3. Kandoth, C.; Schultz, N.; Cherniack, A.D.; Akbani, R.; Liu, Y.; Shen, H.; Robertson, A.G.; Pashtan, I.; Shen, R.; Benz, C.C.; et al. Integrated Genomic Characterization of Endometrial Carcinoma. Nature 2013, 497, 67-73. [CrossRef] [PubMed]

4. PORTEC-4a, Version 2.5.1, 26 June 2020. NCT03469674. Available online: https:/ / clinicaltrials.gov/ct2/show / NCT03469674 (accessed on 10 March 2021).

5. Stelloo, E.; Nout, R.A.; Osse, E.M.; Juergenliemk-Schulz, I.J.; Jobsen, J.J.; Lutgens, L.C.; Van Der Steen-Banasik, E.M.; Nijman, H.W.; Putter, H.; Bosse, T.; et al. Improved Risk Assessment by Integrating Molecular and Clinicopathological Factors in Early-stage Endometrial Cancer-Combined Analysis of the PORTEC Cohorts. Clin. Cancer Res. 2016, 22, 4215-4224. [CrossRef]

6. Concin, N.; Matias-Guiu, X.; Vergote, I.; Cibula, D.; Mirza, M.R.; Marnitz, S.; Ledermann, J.; Bosse, T.; Chargari, C.; Fagotti, A.; et al. ESGO/ESTRO/ESP guidelines for the management of patients with endometrial carcinoma. Radiother. Oncol. 2021, 154, $327-353$. [CrossRef] 
7. Vallone, C.; Rigon, G.; Gulia, C.; Baffa, A.; Votino, R.; Morosetti, G.; Zaami, S.; Briganti, V.; Catania, F.; Gaffi, M.; et al. Non-Coding RNAs and Endometrial Cancer. Genes 2018, 9, 187. [CrossRef]

8. Piergentili, R.; Zaami, S.; Cavaliere, A.F.; Signore, F.; Scambia, G.; Mattei, A.; Marinelli, E.; Gulia, C.; Perelli, F. Non-Coding RNAs as Prognostic Markers for Endometrial Cancer. Int. J. Mol. Sci. 2021, 22, 3151. [CrossRef]

9. Cancer Stat Facts: Uterine Cancer. Available online: https:/ / seer.cancer.gov/statfacts/html/corp.html (accessed on 10 March 2021).

10. Ferlay, J.; Colombet, M.; Soerjomataram, I.; Dyba, T.; Randi, G.; Bettio, M.; Gavin, A.; Visser, O.; Bray, F. Cancer Incidence and Mortality Patterns in Europe: Estimates for 40 Countries and 25 Major Cancers in 2018. Eur. J. Cancer 2018, 103, 356-387. [CrossRef]

11. Braun, M.M.; Overbeek-Wager, E.A.; Grumbo, R.J. Diagnosis and Management of Endometrial Cancer. Am. Fam. Phys. 2016, 93, 468-474.

12. Lu, K.H.; Schorge, J.O.; Rodabaugh, K.J.; Daniels, M.S.; Sun, C.C.; Soliman, P.T.; White, K.G.; Luthra, R.; Gershenson, D.M.; Broaddus, R.R. Prospective Determination of Prevalence of Lynch Syndrome in Young Women with Endometrial Cancer. J. Clin. Oncol. 2007, 25, 5158-5164. [CrossRef]

13. Shaw, E.; Farris, M.; McNeil, J.; Friedenreich, C. Obesity and Endometrial Cancer. Recent Results Cancer Res. 2016, 208, 107-136. [CrossRef]

14. Fung-Kee-Fung, M.; Dodge, J.; Elit, L.; Lukka, H.; Chambers, A.; Oliver, T. Follow-up after Primary Therapy for Endometrial Cancer: A Systematic Review. Gynecol. Oncol. 2006, 101, 520-529. [CrossRef]

15. Amant, F.; Mirza, M.R.; Koskas, M.; Creutzberg, C.L. Cancer of the corpus uteri. Int. J. Gynaecol. Obstet. 2018, 143 (Suppl. S2), 37-50. [CrossRef] [PubMed]

16. Travaglino, A.; Raffone, A.; Stradella, C.; Esposito, R.; Moretta, P.; Gallo, C.; Orlandi, G.; Insabato, L.; Zullo, F. Impact of endometrial carcinoma histotype on the prognostic value of the TCGA molecular subgroups. Arch. Gynecol Obstet. 2020, 301, 1355-1363. [CrossRef] [PubMed]

17. Ritterhouse, L.L.; Howitt, B.E. Molecular Pathology. Surg. Pathol. Clin. 2016, 9, 405-426. [CrossRef]

18. Yu, S.; Shao, H.; Ban, X.; Zhang, H.; You, Y.; Zhou, N.; Mao, X.; Zhao, H.; Chen, J.; Lu, Z. Detection of POLE Subtypes in High-Grade Endometrioid Carcinoma by BaseScope-ISH Assay. Front. Oncol. 2019, 9, 831. [CrossRef] [PubMed]

19. Oldfield, L.E.; Li, T.; Tone, A.; Aronson, M.; Edwards, M.; Holter, S.; Quevedo, R.; Van De Laar, E.; Lerner-Ellis, J.; Pollett, A.; et al. An Integrative DNA Sequencing and Methylation Panel to Assess Mismatch Repair Deficiency. J. Mol. Diagn. 2021, $23,242-252$. [CrossRef] [PubMed]

20. Klaus, A.; Birchmeier, W. Wnt Signalling and Its Impact on Development and Cancer. Nat. Rev. Cancer 2008, 8, 387-398. [CrossRef]

21. Levine, A.J. p53: 800 Million Years of Evolution and 40 Years of Discovery. Nat. Rev. Cancer 2020, 20, 471-480. [CrossRef]

22. Rathjen, F.; Schachner, M. Immunocytological and Biochemical Characterization of a New Neuronal Cell Surface Component (L1 Antigen) Which Is Involved in Cell Adhesion. EMBO J. 1984, 3, 1-10. [CrossRef]

23. Zeimet, A.G.; Reimer, D.; Huszar, M.; Winterhoff, B.; Puistola, U.; Azim, S.A.; Müller-Holzner, E.; Ben-Arie, A.; Van Kempen, L.C.; Petru, E.; et al. L1CAM in Early-Stage Type I Endometrial Cancer: Results of a Large Multicenter Evaluation. J. Natl. Cancer Inst. 2013, 105, 1142-1150. [CrossRef]

24. Handy, D.E.; Castro, R.; Loscalzo, J. Epigenetic Modifications. Circulation 2011, 123, 2145-2156. [CrossRef] [PubMed]

25. Jurcevic, S.; Olsson, B.; Klinga-Levan, K. MicroRNA Expression in Human Endometrial Adenocarcinoma. Cancer Cell Int. 2014, 14, 1-8. [CrossRef] [PubMed]

26. Ouyang, D.; Li, R.; Li, Y.; Zhu, X. Construction of a Competitive Endogenous RNA Network in Uterine Corpus Endometrial Carcinoma. Med. Sci. Monit. 2019, 25, 7998-8010. [CrossRef]

27. Razavi, Z.S.; Tajiknia, V.; Majidi, S.; Ghandali, M.; Mirzaei, H.R.; Rahimian, N.; Hamblin, M.R.; Mirzaei, H. Gynecologic Cancers and Non-coding RNAs: Epigenetic Regulators with Emerging Roles. Crit. Rev. Oncol. 2021, 157, 103192. [CrossRef]

28. Bartosch, C.; Lopes, J.M.; Jerónimo, C. Epigenetics in Endometrial Carcinogenesis—Part 1: DNA Methylation. Epigenomics 2017, 9, 737-755. [CrossRef]

29. Bartosch, C.; Lopes, J.M.; Jerónimo, C. Epigenetics in Endometrial Carcinogenesis-Part 2: Histone Modifications, Chromatin Remodeling and Noncoding RNAs. Epigenomics 2017, 9, 873-892. [CrossRef] [PubMed]

30. Xia, L.; Wang, Y.; Meng, Q.; Su, X.; Shen, J.; Wang, J.; He, H.; Wen, B.; Zhang, C.; Xu, M. Integrated Bioinformatic Analysis of a Competing Endogenous RNA Network Reveals a Prognostic Signature in Endometrial Cancer. Front. Oncol. 2019,9 , 448. [CrossRef]

31. Ala, U. Competing Endogenous RNAs, Non-Coding RNAs and Diseases: An Intertwined Story. Cells 2020, 9, 1574. [CrossRef] [PubMed]

32. Lou, W.; Ding, B.; Fu, P. Pseudogene-Derived lncRNAs and Their miRNA Sponging Mechanism in Human Cancer. Front. Cell Dev. Biol. 2020, 8, 85. [CrossRef] [PubMed]

33. Kumar, S.; Cheng, X.; Klimasauskas, S.; Sha, M.; Posfai, J.; Roberts, R.J.; Wilson, G.G. The DNA (cytosine-5) Methyltransferases. Nucleic Acids Res. 1994, 22, 1-10. [CrossRef] [PubMed]

34. Deaton, A.M.; Bird, A. CpG Islands and the Regulation of Transcription. Genes Dev. 2011, 25, 1010-1022. [CrossRef] [PubMed]

35. Zhao, D.; Ren, C.; Yao, Y.; Wang, Q.; Li, F.; Li, Y.; Jiang, A.; Wang, G. Identifying Prognostic Biomarkers in Endometrial Carcinoma Based on Cerna Network. J. Cell. Biochem. 2019, 121, 2437-2446. [CrossRef] [PubMed] 
36. Wang, Y.; Huang, T.; Sun, X.; Wang, Y. Identification of a Potential Prognostic lncRNA-miRNA-mRNA Signature in Endometrial Cancer Based on the Competing Endogenous RNA Network. J. Cell. Biochem. 2019, 120, 18845-18853. [CrossRef] [PubMed]

37. Gu, Z.-R.; Liu, Q. The LncRNA AL161431.1 Targets miR-1252-5p and Facilitates Cellular Proliferation and Migration via MAPK Signaling in Endometrial Carcinoma. Eur. Rev. Med. Pharmacol. Sci. 2020, 24, 2294-2302. [PubMed]

38. Liu, J.; Nie, S.; Liang, J.; Jiang, Y.; Wan, Y.; Zhou, S.; Cheng, W. Competing Endogenous RNA Network of Endometrial Carcinoma: A Comprehensive Analysis. J. Cell. Biochem. 2019, 120, 15648-15660. [CrossRef]

39. Yu, J.; Jiang, L.; Gao, Y.; Sun, Q.; Liu, B.; Hu, Y.; Han, X. LncRNA CCAT1 Negatively Regulates miR 181a 5p to Promote Endometrial Carcinoma Cell Proliferation and Migration. Exp. Ther. Med. 2019, 17, 4259-4266. [CrossRef]

40. Treeck, O.; Skrzypczak, M.; Schüler-Toprak, S.; Weber, F.; Ortmann, O. Long Non-coding RNA CCAT1 Is Overexpressed in Endometrial Cancer and Regulates Growth and Transcriptome of Endometrial Adenocarcinoma Cells. Int. J. Biochem. Cell Biol. 2020, 122, 105740. [CrossRef]

41. Xie, P.; Cao, H.; Li, Y.; Wang, J.; Cui, Z. Knockdown of lncRNA CCAT2 Inhibits Endometrial Cancer Cells Growth and Metastasis via Sponging miR-216b. Cancer Biomark. 2017, 21, 123-133. [CrossRef]

42. Shang, C.; Ao, C.N.; Cheong, C.C.; Meng, L. Long Non-coding RNA CDKN2B Antisense RNA 1 Gene Contributes to Paclitaxel Resistance in Endometrial Carcinoma. Front. Oncol. 2019, 9, 27. [CrossRef]

43. Shi, Y.; Zha, J.; Zuo, M.; Yan, Q.; Song, H. Long Noncoding RNA CHL1-AS1 Promotes Cell Proliferation and Migration by Sponging miR-6076 to Regulate CHL1 Expression in Endometrial Cancer. J. Cell. Biochem. 2019, 121, 2655-2663. [CrossRef]

44. Shen, Q.; He, T.; Yuan, H. Hsa_circ_0002577 Promotes Endometrial Carcinoma Progression via Regulating miR-197/CTNND1 Axis and Activating Wnt/ $\beta$-Catenin Pathway. Cell Cycle 2019, 18, 1229-1240. [CrossRef] [PubMed]

45. Xu, H.; Gong, Z.; Shen, Y.; Fang, Y.; Zhong, S. Circular RNA Expression in Extracellular Vesicles Isolated from Serum of Patients with Endometrial Cancer. Epigenomics 2018, 10, 187-197. [CrossRef]

46. Liu, Y.; Chang, Y.; Cai, Y. Hsa_circ_0061140 Promotes Endometrial Carcinoma Progression via Regulating miR-149-5p/STAT3. Gene 2020, 745, 144625. [CrossRef] [PubMed]

47. Sun, J.; Gao, S.; Lu, C. Knockdown of Differentiation Antagonizing Non-protein Coding RNA Exerts Anti-tumor Effect by up-Regulating miR-214 in Endometrial Carcinoma. Mol. Cell. Biochem. 2019, 460, 9-15. [CrossRef] [PubMed]

48. Shao, W.; Li, Y.; Chen, F.; Jia, H.; Jia, J.; Fu, Y. Long Non-Coding RNA DLEU1 Contributes to the Development of Endometrial Cancer by Sponging miR-490 to Regulate SP1 Expression. Die Pharm. 2018, 73, 379-385.

49. Du, Y.; Wang, L.; Chen, S.; Liu, Y.; Zhao, Y. IncRNA DLEU1 Contributes to Tumorigenesis and Development of Endometrial Carcinoma by Targeting mTOR. Mol. Carcinog. 2018, 57, 1191-1200. [CrossRef]

50. Tanos, V.; Ariel, I.; Prus, D.; De-Groot, N.; Hochberg, A. H19 and IGF2 Gene Expression in Human Normal, Hyperplastic, and Malignant Endometrium. Int. J. Gynecol. Cancer 2004, 14, 521-525. [CrossRef] [PubMed]

51. Lottin, S.; Adriaenssens, E.; Berteaux, N.; Lepretre, A.; Vilain, M.-O.; Denhez, E.; Coll, J.; Dugimont, T.; Curgy, J.-J. The Human H19 Gene Is Frequently Overexpressed in Myometrium and Stroma during Pathological Endometrial Proliferative Events. Eur. J. Cancer 2005, 41, 168-177. [CrossRef] [PubMed]

52. Zhao, L.; Li, Z.; Chen, W.; Zhai, W.; Pan, J.; Pang, H.; Li, X. H19 Promotes Endometrial Cancer Progression by Modulating Epithelial-Mesenchymal Transition. Oncol. Lett. 2017, 13, 363-369. [CrossRef]

53. Zhang, L.; Wang, D.-L.; Yu, P. LncRNA H19 Regulates the Expression of Its Target Gene HOXA10 in Endometrial Carcinoma through Competing With miR-612. Eur. Rev. Med. Pharmacol. Sci. 2018, 22, 4820-4827.

54. Zhu, H.; Jin, Y.-M.; Lyu, X.-M.; Fan, L.-M.; Wu, F. Long Noncoding RNA H19 Regulates HIF-1 $\alpha /$ AXL Signaling through Inhibiting miR-20b-5p in Endometrial Cancer. Cell Cycle 2019, 18, 2454-2464. [CrossRef]

55. Liu, S.; Qiu, J.; Tang, X.; Cui, H.; Zhang, Q.; Yang, Q. LncRNA-H19 Regulates Cell Proliferation and Invasion of Ectopic Endometrium by Targeting ITGB3 via Modulating miR-124-3p. Exp. Cell Res. 2019, 381, 215-222. [CrossRef]

56. He, X.; Bao, W.; Li, X.; Chen, Z.; Che, Q.; Wang, H.; Wan, X.-P. The Long Non-coding RNA HOTAIR Is Upregulated in Endometrial Carcinoma and Correlates with Poor Prognosis. Int. J. Mol. Med. 2013, 33, 325-332. [CrossRef]

57. Huang, J.; Ke, P.; Guo, L.; Wang, W.; Tan, H.; Liang, Y.; Yao, S. Lentivirus-Mediated RNA Interference Targeting the Long Noncoding RNA HOTAIR Inhibits Proliferation and Invasion of Endometrial Carcinoma Cells In Vitro and In Vivo. Int. J. Gynecol. Cancer 2014, 24, 635-642. [CrossRef] [PubMed]

58. Sun, M.-Y.; Zhu, J.-Y.; Zhang, C.-Y.; Zhang, M.; Song, Y.-N.; Rahman, K.; Zhang, L.-J.; Zhang, H. Autophagy Regulated by lncRNA HOTAIR Contributes to the Cisplatin-Induced Resistance in Endometrial Cancer Cells. Biotechnol. Lett. 2017, 39, 1477-1484. [CrossRef] [PubMed]

59. Zhou, Y.-X.; Wang, C.; Mao, L.-W.; Wang, Y.-L.; Xia, L.-Q.; Zhao, W.; Shen, J.; Chen, J. Long Noncoding RNA HOTAIR Mediates the Estrogen-Induced Metastasis of Endometrial Cancer Cells via the miR-646/NPM1 Axis. Am. J. Physiol. Physiol. 2018, 314, C690-C701. [CrossRef] [PubMed]

60. Chi, S.; Liu, Y.; Zhou, X.; Feng, D.; Xiao, X.; Li, W.; Zhao, Y.; Wang, H. Knockdown of Long Non-coding HOTAIR Enhances the Sensitivity to Progesterone in Endometrial Cancer by Epigenetic Regu-Lation of Progesterone Receptor Isoform, B. Cancer Chemother. Pharmacol. 2019, 83, 277-287. [CrossRef] [PubMed]

61. Zhang, X.-H.; Hu, P.; Xie, Y.-Q.; Kang, Y.-J.; Li, M. Long Noncoding RNA HOTAIR Promotes Endometrial Carcinoma Cell Proliferation by Binding to PTEN via the Activating Phosphatidylinositol 3-Kinase/Akt Signaling Pathway. Mol. Cell. Biol. 2019, 39, e00251-19. [CrossRef] [PubMed] 
62. Li, X.; Pang, L.; Yang, Z.; Liu, J.; Li, W.; Wang, D. LncRNA HOTAIRM1/HOXA1 Axis Promotes Cell Proliferation, Migration and Invasion in Endometrial Cancer. OncoTargets Ther. 2019, 12, 10997-11015. [CrossRef] [PubMed]

63. Liu, D.; Qiu, M.; Jiang, L.; Liu, K. Long Noncoding RNA HOXB-AS1 Is Upregulated in Endometrial Carcinoma and Sponged miR-149-3p to Upregulate Wnt10b. Technol. Cancer Res. Treat. 2020, 19, 153303382096746. [CrossRef]

64. Pan, X.; Li, D.; Huo, J.; Kong, F.; Yang, H.; Ma, X. LINC01016 Promotes the Malignant Phenotype of Endometrial Cancer Cells by Regulating the miR-302a-3p/miR-3130-3p/NFYA/SATB1. Cell Death Dis. 2018, 9, 303. [CrossRef] [PubMed]

65. Lu, M.; Ding, N.; Zhuang, S.; Li, Y. LINC01410/miR-23c/CHD7 Functions as a ceRNA Network to Affect the Prognosis of Patients with Endometrial Cancer and Strengthen the Malignant Properties of Endometrial Cancer Cells. Mol. Cell. Biochem. 2020, 469, 9-19. [CrossRef] [PubMed]

66. Zhou, X.; Gao, Q.; Wang, J.; Zhang, X.; Liu, K.; Duan, Z. Linc-RNA-RoR Acts as a "Sponge" against Mediation of the Differentiation of Endometrial Cancer Stem Cells by microRNA-145. Gynecol. Oncol. 2014, 133, 333-339. [CrossRef]

67. Liu, Y.; Chang, Y.; Cai, Y.-X. Inhibition of Lnc-OC1 Induced Cell Apoptosis and Decreased Cell Viability by Releasing miR-34a and Inhibiting PD-L1 in Endometrial Carcinoma. Reprod. Sci. 2020, 27, 1848-1856. [CrossRef]

68. Zheng, X.; Liu, M.; Song, Y.; Feng, C. Long Noncoding RNA-ATB Impairs the Function of Tumor Suppressor miR-126-Mediated Signals in Endometrial Cancer for Tumor Growth and Metastasis. Cancer Biother. Radiopharm. 2019, 34, 47-55. [CrossRef]

69. Yang, X.; Xing, G.; Liu, S.; Li, B.; He, Y.; Wang, F. LncRNA LOXL1-AS1 Promotes Endometrial Cancer Progression by Sponging miR-28-5p to Upregulate RAP1B Expression. BioMed. Pharmacother. 2020, 125, 109839. [CrossRef]

70. Wang, W.; Ge, L.; Xu, X.-J.; Yang, T.; Yuan, Y.; Ma, X.-L.; Zhang, X.-H. LncRNA NEAT1 Promotes Endometrial Cancer Cell Proliferation, Migration and Invasion by Regulating the miR-144-3p/EZH2 Axis. Radiol. Oncol. 2019, 53, 434-442. [CrossRef] [PubMed]

71. Dong, P.; Xiong, Y.; Yue, J.; Xu, D.; Ihira, K.; Konno, Y.; Kobayashi, N.; Todo, Y.; Watari, H. Long Noncoding RNA NEAT1 Drives Aggressive Endometrial Cancer Progression via Mir-361-Regulated Networks Involving STAT3 and Tumor Microenvi-RonmentRelated Genes. J. Exp. Clin. Cancer Res. 2019, 38, 1-15. [CrossRef] [PubMed]

72. Huang, X.; Zhong, R.; He, X.; Deng, Q.; Peng, X.; Li, J.; Luo, X. Investigations on the Mechanism of Progesterone in Inhibiting Endometrial Cancer Cell Cycle and Viability via Regulation of Long Noncoding RNA NEAT1/microRNA-146b-5p Mediated Wnt/ $\beta$-catenin signaling. IUBMB Life 2019, 71, 223-234. [CrossRef] [PubMed]

73. Wang, L.; Zhao, S.; Mingxin, Y.U. LncRNA NR2F1-AS1 Is Involved in the Progression of Endometrial Cancer by Sponging miR-363 to target SOX4. Die Pharm. 2019, 74, 295-300.

74. Li, Q.; Shen, F.; Zhao, L. The Relationship between lncRNA PCGEM1 and STAT3 During the Occurrence and Development of Endometrial Carcinoma. BioMed. Pharmacother. 2018, 107, 918-928. [CrossRef]

75. Kong, F.; Ma, J.; Yang, H.; Yang, D.; Wang, C.; Ma, X. Long Non-Coding RNA PVT1 Promotes Malignancy in Human Endometrial Carcinoma Cells through Negative Regulation of miR-195-5p. Biochim. Biophys. Acta Bioenerg. 2018, 1865, 1479-1490. [CrossRef] [PubMed]

76. Xing, T.-R.; Chen, P.; Wu, J.-M.; Gao, L.-L.; Yang, W.; Cheng, Y.; Tong, L.-B. UPF1 Participates in the Progression of Endometrial Cancer by Inhibiting the Expression of IncRNA PVT1. Onco Targets Ther. 2020, 13, 2103-2114. [CrossRef]

77. Gao, L.; Nie, X.; Zhang, W.; Gou, R.; Hu, Y.; Qi, Y.; Li, X.; Liu, Q.; Liu, J.; Lin, B. Identification of Long Noncoding RNA RP11-89K21.1 and RP11-357H14.17 as Prognostic Signature of Endometrial Carcinoma via Integrated Bioinformatics Analysis. Cancer Cell Int. 2020, 20, 268. [CrossRef]

78. Zhang, G.; Ma, A.; Jin, Y.; Pan, G.; Wang, C. LncRNA SNHG16 Induced by TFAP2A Modulates Glycolysis and Proliferation of Endometrial Carcinoma Through miR-490-3p/HK2. Am. J. Transl. Res. 2019, 11, 7137-7145.

79. Yang, C.-H.; Zhang, X.-Y.; Zhou, L.-N.; Wan, Y.; Song, L.-L.; Gu, W.-L.; Liu, R.; Ma, Y.-N.; Meng, H.-R.; Tian, Y.-L.; et al. LncRNA SNHG8 Participates in the Development of Endometrial Carcinoma through Regulating c-MET Expression by miR-152. Eur. Rev. Med. Pharmacol. Sci. 2018, 22, 1629-1637.

80. Liu, L.; Chen, X.; Zhang, Y.; Hu, Y.; Shen, X.; Zhu, W. Long Non-Coding RNA TUG1 Promotes Endometrial Cancer Development via Inhibiting miR-299 and miR-34a-5p. Oncotarget 2017, 8, 31386-31394. [CrossRef]

81. Ke, J.; Shen, Z.; Hu, W.; Li, M.; Shi, Y.; Xie, Z.; Wu, D. LncRNA DCST1-AS1 Was Upregulated in Endometrial Carcinoma and May Sponge miR-92a-3p to Upregulate Notch1. Cancer Manag. Res. 2020, 12, 1221-1227. [CrossRef] [PubMed]

82. Kong, Y.; Ren, Z. Overexpression of LncRNA FER1L4 in Endometrial Carcinoma Is Associated with Favorable Survival Out-come. Eur. Rev. Med. Pharmacol. Sci. 2018, 22, 8113-8118. [CrossRef] [PubMed]

83. Guo, C.; Song, W.-Q.; Sun, P.; Jin, L.; Dai, H.-Y. LncRNA-GAS5 Induces PTEN Expression through Inhibiting miR-103 in Endometrial Cancer Cells. J. BioMed. Sci. 2015, 22, 100. [CrossRef]

84. Xin, W.; Zhao, S.; Han, X.; Zhao, P.; Yu, H.; Gao, X.; Li, P.; Wu, Q.; Ding, J.; Hua, K. IncRNA LA16c-313D11.11 Modulates the Development of Endometrial Cancer by Binding to and Inhibiting microRNA 2055 p Function and Indirectly in-Creasing PTEN activity. Int. J. Oncol. 2020, 57, 355-363. [CrossRef]

85. Fang, Q.; Sang, L.; Du, S. Long Noncoding RNA LINC00261 Regulates Endometrial Carcinoma Progression by Modulating miRNA/FOXO1 Expression. Cell Biochem. Funct. 2018, 36, 323-330. [CrossRef] [PubMed]

86. Xu, H.; Sun, Y.; Ma, Z.; Xu, X.; Qin, L.; Luo, B. LOC134466 Methylation Promotes Oncogenesis of Endometrial Carcinoma Through LOC134466/hsa-miR-196a-5p/TAC1 axis. Aging 2018, 10, 3353-3370. [CrossRef] 
87. Li, Q.; Zhang, C.; Chen, R.; Xiong, H.; Qiu, F.; Liu, S.; Zhang, M.; Wang, F.; Wang, Y.; Zhou, X.; et al. Disrupting MALAT1/miR-200c Sponge Decreases Invasion and Migration in Endometrioid Endometrial Carcinoma. Cancer Lett. 2016, 383, 28-40. [CrossRef]

88. Shi, F.; Wang, T.; Liu, Z.; Zhang, Y.; Wang, J.; Zhang, K.; Su, J. LncRNA miR143HG Up-Regulates p53 In Endometrial Carcinoma by Sponging miR-125a. Cancer Manag. Res. 2019, 11, 10117-10123. [CrossRef]

89. Cui, Z.; An, X.; Li, J.; Liu, Q.; Liu, W. LncRNA MIR22HG Negatively Regulates miR-141-3p to Enhance DAPK1 Expression and Inhibits Endometrial Carcinoma Cells Proliferation. BioMed. Pharmacother. 2018, 104, 223-228. [CrossRef]

90. Zhou, Y.-X.; Zhao, W.; Mao, L.-W.; Wang, Y.-L.; Xia, L.-Q.; Cao, M.; Shen, J.; Chen, J. Long Non-Coding RNA NIFK-AS1 Inhibits M2 Polarization of Macrophages in Endometrial Cancer through Targeting miR-146a. Int. J. Biochem. Cell Biol. 2018, $104,25-33$. [CrossRef] [PubMed]

91. Xin, W.; Gao, X.; Zhao, S.; Zhao, P.; Yu, H.; Wu, Q.; Hua, K. LncRNA RP11-395G23.3 Suppresses the Endometrial Cancer Progression via Regulating microRNA-205-5p/PTEN axis. Am. J. Transl. Res. 2020, 12, 4422-4433.

92. Li, S.; Shan, Y.; Li, X.; Zhang, C.; Wei, S.; Dai, S.; Zhao, R.; Zhao, X.; Zhao, L.; Shan, B. IncRNA SNHG5 Modulates Endometrial Cancer Progression via the miR-25-3p/BTG2 Axis. J. Oncol. 2019, 2019, 7024675. [CrossRef] [PubMed]

93. Shang, C.; Lang, B.; Ao, C.N.; Meng, L. Long Non-Coding RNA Tumor Suppressor Candidate 7 Advances Chemotherapy Sensitivity of Endometrial Carcinoma through Targeted Silencing of miR-23b. Tumor Biol. 2017, 39, 1010428317707883. [CrossRef] [PubMed]

94. Wu, X.; Cai, D.; Zhang, F.; Li, M.; Wan, Q. Long Noncoding RNA TUSC7 Inhibits Cell Proliferation, Migration and Invasion by Regulating SOCS4 (SOCS5) Expression through Targeting miR-616 in Endometrial Carcinoma. Life Sci. 2019, $231,116549$. [CrossRef]

95. Wang, Y.; Liu, Y.; Guan, Y.; Li, H.; Liu, Y.; Zhang, M.; Cui, P.; Kong, D.; Chen, X.; Yin, H. Integrated analysis of immune-related genes in endometrial carcinoma. Cancer Cell Int. 2020, 20, 477. [CrossRef]

96. Tang, H.; Wu, Z.; Zhang, Y.; Xia, T.; Liu, D.; Cai, J.; Ye, Q. Identification and Function Analysis of a Five-Long Noncoding RNA Prognostic Signature for Endometrial Cancer Patients. DNA Cell Biol. 2019, 38, 1480-1498. [CrossRef]

97. Zhao, X.; Fan, Y.; Lu, C.; Li, H.; Zhou, N.; Sun, G.; Fan, H. PCAT1 is a poor prognostic factor in endometrial carcinoma and associated with cancer cell proliferation, migration and invasion. Bosn. J. Basic Med. Sci. 2019, 19, 274-281. [CrossRef] [PubMed]

98. Dwivedi, S.K.D.; Rao, G.; Dey, A.; Mukherjee, P.; Wren, J.D.; Bhattacharya, R. Small Non-Coding-RNA in Gynecological Malignancies. Cancers 2021, 13, 1085. [CrossRef]

99. Miki, Y. New Insights into Breast and Endometrial Cancers. Cancers 2020, 12, 2595. [CrossRef] [PubMed] 